\title{
The Conqueror Meets the Unconquered: Negotiating Cultural Boundaries on the Post-Revolutionary Southern Frontier
}

\author{
By GREG O'BRIEN
}

\begin{abstract}
$\mathrm{O}$
NeCEMBer 26, 1785, a Group of 127 Bedraggled Choctaw Indians arrived at Hopewell, Andrew Pickens's home on the Keowee River in South Carolina. They had trekked for over two months and traveled hundreds of miles from their central Mississippi homeland to represent the Choctaw people in a meeting with representatives of the United States government. Several days of negotiations resulted in the first treaty between these two powers. This encounter in the southern backcountry (which was the second in a series of three consecutive meetings at Hopewell during the winter of 1785-1786 between the U.S. and the Cherokees, Choctaws, and Chickasaws, respectively) reveals several issues vital to an understanding of intercultural relations in the post-Revolutionary War South.'

Since the extant transcripts of these negotiations have never been published, previous accounts of the Choctaw Hopewell Treaty have relied exclusively on the written and signed treaty as the basis for what
\end{abstract}

' William H. Masterson, William Blount (Baton Rouge, 1954), 107. For background on Pickens and his home see Alice Noble Waring, The Fighting Elder: Andrew Pickens, 1739 -1817 (Columbia, S.C., 1962). Estimates of the Choctaw population in the late eighteenth century range from around 14,000 up to 30,000; see Peter H. Wood, "The Changing Population of the Colonial South: An Uverview by Race and Region, 1685-1790," in Peter H. Wood, Gregory A. Waselkov, and M. Thomas Hatley, eds., Powhatan's Mantle: Indians in the Colonial Southeast (Lincoln, Neh., and Iondon, 1989), 38, 72; Richard White. The Roots of Dependency: Subsistence, Environment, and Social Change among the Choctaws, Pawnees, and Navajos (Lincoln, Neb., 1983), 5; and Daniel H. Usner Jr., American Indians in the Lower Mississippi Valley: Social and Economic Histories (Lincoln, Neb., and London, 1998), 35.

I wish to thank Michael Green, Theda Perdue, Daniel Richter, Nancy Shoemaker, and the anonymous reviewers for the Journal of Southern History for commenting and making valuable suggestions on earlier drafts of this essay.

MR. O'BRIEN is an assistant professor of history at the University of Southern Mississippi. 
each side agreed to and tried to accomplish. ${ }^{2}$ Such accounts have told an accordingly simplistic story of Indian acquiescence to American demands. ${ }^{3}$ A close examination of the talks and the rituals that accompanied them reveals a picture different from that presented by the treaty itself, including what each side tried to accomplish at Hopewell, their attempts to accommodate one another, and the diversity of diplomatic expression and language employed by American Indians and Euro-Americans in the post-Revolutionary South. An analysis of the Hopewell treaty negotiations from the perspectives of both participants exposes two societies acting in accordance with inherited tradition and utilizing new approaches arising from their Revolutionary War experience. Such reconsideration also calls into question whether the model of a "middle ground" of interaction between Native Americans and Europeans-which has been employed by some recent scholars to describe a zone where different peoples borrowed certain cultural practices from one another in the interest of civility and peace-can be applied uncritically. ${ }^{4}$

\footnotetext{
${ }^{2}$ Joseph Martin was Virginia's designated representative to the Hopewell meetings, and his handwritten "Journal of the Hopewell Treaties, 1786" is in the Draper Manuscript Collection (State Historical Society of Wisconsin, Madison), Series U, Vol, 14, pp. 56-92, which is also available on microfilm (Madison, 1944-1949, reel 65) (hereinafter cited as Martin journal). Benjamin Hawkins, North Curolina's representative to the negotiations, transcribed a copy of Martin's journal, and it resides in the Joseph Valliance Bevan Papers, Series 7E, Itern 11 of the Peter Force Collection (Manuscript Division, Library of Congress, Washington, D.C.).

See Walter H. Mohr, Fe'teral Indian Relations, 1774-1788 (Philadelphia, 1933), 151-56; Waring, The Fighting Elder, 135; Reginald Horsman, Expansion and American Indian Policy, 1783-1812 (East Lansing, Mich., 1967), 29-30; W. David Baird, Peter Pitchlynn: Chief of the Choctaws (Norman, Okla., 1972), 8; John D. Guice, "Face to Face in Mississippi Territory. 1798-1817," in Carolyn Keller Reeves, ed., The Choctaw Before Removal (Jackson, Miss., 1985), 164; Samuel J. Wells, "Federal Indian Policy: From Accomodation to Removal," in Reeves, ed., Choclaw Before Removal, 183; Robert B. Ferguson, "Appendix: Treaties between the United States and the Choctaw Nation," in Reeves, ed., Choctaw Before Removal, 214-15; Francis Paul Prucha, The Great Father: The United States Government and the American Indians (2 vols; I incoln, Neb., 1984), 1, 46: and Prucha, American Indian Treaties: The History of a Politicul Anomaly (Berkeley, Los Angeles, and London, 1994), 62-63.

"For the original concept of the "middle ground," which emphasized cultural competition and violence as much as cultural borrowing and civility, see Richard White, The Middle Ground: Indians, Empires, und Republics in the Great Lakes Region, 1650-1815 (Cambridge, Eng., and other cities, 1991). More recent works have advanced an "alternative vision of peaceful coexistence and creative accommodation" between Europeans and Indians; see Andrew R. L. Cayton and Fredrika J. Teute, eds., Contact Points: American Frontiers from the Mohawk Valley to the Mississippi, 1750-1830 (Chapel Hill and London, 1998), 9. For an essay critical of such revi. sionism, see Daniel J. Herman. "Romance on the Middle Ground," Journal of the Early Republic, XIX (Summer 1999), 279-91. Other recent works that analyze in greater detail the contrasting meanings of metaphors and actions utilized by Indians and Europeans in colonial and early national America include several of the essays in Cayton and Teute, eds., Contact Points. On the importance of analyzing treaty council proceedings to ohserve the "clash of two idea systems" between Indians and Euro-Americans, see Raymond J. DeMallie, "Touching the Pen: Plains
} 
The years between the end of the Revolutionary War and the establishment of a new United States government under the Constitution were a crucial, albeit brief, period of transition during which many Indian groups east of the Mississippi River still operated according to centuries-old notions of proper behavior and the United States had not yet established hegemony over the lands supposedly under its jurisdiction. Scholars using 20/20 hindsight from a later time when Americans had militarily defeated most of the eastern Indians too easily forget that reality. In order to fully appreciate the diverse motivations, tactics, and happenings at play in the post-Revolutionary southern backcountry, the Indian side to the equation and a sense of uncertainty about the eventual outcome must be restored to the historical record. ${ }^{5}$

Choctaw relations with Europeans underwent several permutations in the years preceding the Hopewell Treaty. France supplied the bulk of trade goods and was the main European ally for the Choctaws living in present-day east-central Mississippi from the early eighteenth century until the end of the Seven Years War in 1763. Britain also made sporadic inroads into the Choctaw trade before 1763, often at the request of Choctaw chiefs, and served as the principal trade ally for the Choctaws from that year until 1781. Spain occupied New Orleans in 1766, holding occasional meetings with various Choctaws and allowing Choctaw deerskin traders to conduct business there, despite British wishes that the Choctaws trade with them alone. In June 1779, during the turmoil of the American Revolution, Spain declared war on Great Britain, and military forces under Governor Bernardo de Gálvez promptly defeated British soldiers along the east bank of the Mississippi River at Manchac, Baton Rouge, and Natchez. Mobile fell to Spain in March 1780, and Pensacola followed in May 1781. For the remainder of the century Spain and the United States vied for control of the southeastern Mississippi Valley. ${ }^{6}$

Indian Treaty Councils in Ethnohistorical Perspective," in Frederick C. Luebke, ed., Ethnicity on the Great Plains (Lincoln, Neb., and London, 1980), 38-40; and James H. Merrell, Into the American Woods: Negotiators on the Pennsylvania Frontier (New York. 1999).

${ }^{5}$ By contrast, see the promotion of the official American line in Prucha, American Indian Treaties. 65-66, where he wrote: "[T]he Indians agreed to a considerable diminution of their autonomy [in 1786] when they accepted peace given by the United States, agreed to be under its protection, and acquiesced in the treaty provisions that Congress would have 'the sole and exclusive right of regulating the trade with the Indians, and managing all their affairs in such manner as they think proper'."

${ }^{6}$ Warren Gregory O'Brien, "Choctaws in a Revolutionary Age: A Study of Power and Authority, 1750-1801" (Ph.D. dissertation, University of Kentucky, 1998), 108-10; and Greg O'Brien, "Protecting Trade through War: Choctaw Elites and British Occupation of the Floridas," in Martin Daunton and Rick Halpern, eds., Empire and Others: British Encounters with 
This simple Eurocentric account of military and diplomatic events masks an underlying complexity: Choctaw society was divided into three distinct political and geographic divisions, a reality that lends an added, and often disregarded, dimension to Choctaw diplomacy. During the American Revolution some Choctaw warriors, primarily from the western and eastern divisions, fought in support of British forces protecting Mobile and Pensacola. In 1778 a western division war party of about 150 men, along with a handful of British officers and traders, occupied Natchez in the late spring and early summer. The group hoped to prevent additional American raids down the Mississippi River like the one that had been carried out by Captain James Willing in February of that year. The Choctaw war leader Franchimastabé warned the citizens of Natchez to remain pro-British, putting them on notice that "should you offer to take the rebels by the hand or enter into any treaty with them, remember also that we are behind you and that we will look on you as Virginians and treat you as our enemies."7 Choctaw warriors from the Six Towns division, on the other hand, assisted the Spanish in taking Mobile and Pensacola from the British, although, presumably by design, no Choctaw warriors fought against each other. ${ }^{8}$

Such divisional autonomy made Choctaw governance more akin to a confederacy than a "nation." It also made it easier for them to "playoff" one European country against another in diplomacy, since Europeans could never be sure exactly where Choctaw loyalties lay.

Indigenous Peoples, 1600-1850 (Philadelphia and London, 1999), 149-66. Spain's defeat of British forces in the Southeast is summarized neatly in David J. Weber. The Spanish Frontier in North America (New Haven and London, 1992), 265-70.

${ }^{7}$ Farquhar Bethune to John Stuart [British Superintendent of Southern Indian Affairs]. June 16. 1778, in K. G. Davies, ed., Documents of the American Revolution, 1770-1783. Colonial Office Series (21 vols,; Shannon, Ireland, 1972-1981), XV, 143-45 (quotation on p. 145); see also Davies's description of the events of 1778, pp. 12-15. The Choctaw confederacy was composed of three principal ethnic and geographical groupings called the Okla falaya ("people who are widely dispersed"), Okla tannap ("people from the other side"), and Okla hannali ("people of six towns"). Eighteenth-century Europeans and subsequent scholars have simplified this terminology into the western, eastern, and Six Towns (or southern) divisions, respectively. See White, Roots of Dependency, 37-38, 106-8; Patricia Galloway, "Confederacy as a Solution to Chiefdom Dissolution: Historical Evidence in the Choctaw Case," in Charles Hudson and Carmen Chaves Tesser, eds., The Forgotten Centuries: Indians and Europeans in the American Suuth, 152J-1704 (Athens, Ga., and London, 1994), 408-9; Galloway, Choctaw Genesis, 15001700 (Lincoln, Neb., and London, 1995), 338-60; and John R. Swanton, Source Material for the Social and Ceremonial Life of the Choctaw Indians (Bureau of American Ethnology Bulletin 103, Washington, D.C., 1931). 55-56.

${ }^{8}$ For Choctaw assistance to Spain see Carnline Maude Burson, The Stewardship of Don Esteban Miro, 1782-1792 (New Orleans, 1940), 48; for Choctaw aid to the British see James H. O'Donnell III, Southern Indians in the American Revolution (Knoxville, Tenn., 1973), and O'Brien, "Choctaws in a Revolutionary Age," 108-10. 
While the country that supplied the Choctaws with the greatest quantity and quality of gifts could often feel assured of their influence over Choctaw military actions, their loyalty was never guaranteed. ${ }^{9}$ As the British presence in the South diminished to nothing by 1783, with the abandonment of posts in Charleston, Savannah, and St. Augustine, Choctaws searched creatively for ways to reestablish the "play-off" system and the flow of trade goods. Three potential sources of trade existed for the Choctaws: Spain and their British-operated trading companies (such as the Mather and Strother Company and Panton, Leslie and Company), individual American states such as Georgia and South Carolina, or the new national government of the United States. ${ }^{10}$

Choctaw chiefs responded to the post-Revolutionary situation by seeking to increase trade with all of these groups. In July 1784 separate Choctaw delegations representing all three divisions met simultaneously with Spain at Mobile and with the Georgia government in Savannah to establish peaceful relations and resume trade. " European manufactured goods provided an essential part of Choctaw material life, as they did for Indians throughout eastern North America by the late eighteenth century. In the Southeast, Euro-American traders and officials offered guns, bullets, hatchets, hoes, brass and tin kettles, needles, knives, scissors, woolen cloth, shirts, blankets, paint, earrings, armbands, buttons, rum, and even Jew's harps in return for deerskins, bear fat oil, and other animal products. ${ }^{12}$ Manufactured commodities made hunting, warfare, agriculture, domestic chores, rituals, and beautification easier for Indians. Many of these items - such as kettles that were cut up and used as arrowheads, knives, and adornment-were

\footnotetext{
"European officials used the term "nation" to refer to Indian societies such as the Choctaws for decades before the 1780s, but "confederacy" or the more ambiguous but less misleading "group" offers a more accurate assessment of Choctaw political realities. while also avoiding the sometimes pejorative "tribe." On the Choctaw "play-off" system see White. Roots of Dependency, $34-68$.

"1"For the British-operated trading companies hired by Spain see William S. Coker and Thomas D. Watson, Indian Traders of the Southeastern Spanish Borderlands: Panton, Lestie \& Company and John Forbes \& Company, 1783-1847 (Pensacola, Fla., 1986).

"For the Spanish treaty see "Tratado de alianza entre España y los indios Chactas y Chicasas - Chicachas, 14 de Julio de 1784," in Manuel Serrano y Sanz, España y los Indios Cherokis y Chactas en la Segunda Mitad del Siglo XVIII (Seville, Spain, 1916), 82-85. On the meeting with Georgia see John Woods to [Georgia Lieutenant Governor] John Habersham, June 12, 1784, and "Talk Delivered by Habersham to Mingahoopa the Second Chief of the Choctaw Nation, July 17. 1784," in Louise Frederick Hays, ed., Creek Indian Letters, Talks, and Treaties, 1705-1839 (4 vols.; Atlanta, 1939), 1, 56, 59-60).

${ }^{12}$ For analysis of the Creek deerskin trade see Kathryn E. Holland Braund, Deerskins and Duffels: The Creek Indian Trade with Anglo-America, 1685-1815 (Lincoln, Neb., and London, 1993).
} 
altered from their original form and used in ways more congruent with native views of practicality or even cosmology. ${ }^{13}$ Since at least Mississippian times (ca. 1000-1600), Choctaws and their predecessors had expected their chiefs to acquire rare, prestige-laden foreign goods for the use of the community. Acquisition of such items bolstered the authority of chiefs because it required them to negotiate with the outside world and foreign peoples, which only diplomatic specialists who had mastered spiritual power could accomplish. Furthermore, a chief secured reciprocal obligations by redistributing trade items to his family and supporters. Distributing foreign manufactured items also bolstered leaders' status within Choctaw society, and demands for trade may have been motivated as much or more by their desire to accrue status as by material needs. ${ }^{14}$ Beginning in the 1760 s, however, unregulated British trade increasingly democratized the barter system among southern Indians because traders exchanged their products with any Indian who had skins rather than obeying Indian custom by acting through established chiefs. As a result, Choctaw chiefs sought new ways to funnel goods through their own hands, and treaty negotiations offered them just such an opportunity. ${ }^{15}$

In the summer of 1785 two American delegations arrived in the Choctaw village of West Yazoo in the western division. The first contingent came from Georgia to assert that state's claim to lands all the way to the Mississippi River, while also promising trade and "commissions" to Choctaw warriors. The principal chief of West Yazoo,

\footnotetext{
${ }^{13}$ Christopher L. Miller and George R. Hamell, "A New Perspective on Indian-White Contact: Cultural Symbols and Colonial Trade." Journal of American History, LXXIII (September 1986), 311-28. For lists of the items being traded to the Choctaws see Helen Louise Shaw. British Administration of the Southern Indians, 1756-1783 (Lancaster, Pa., 1931), 70. 166-72; White, Roots of Dependency; and Daniel H. Usner Jr., Indians. Settlers, and Slaves in a Frontier Exchange Economy: The Lower Mississippi Valley Before 1783 (Chapel Hill and London, 1992), 260, 270-72.

${ }^{14}$ Jon D. Muller, "The Southeast," in Jesse D. Jennings, ed., Ancient Native Americans (San Francisco, 1978), 281-325; Alex W. Barker and Timothy R. Pauketat, eds., Lords of the Southeast: Social Inequality and the Native Elites of Southeastern North America. Archeological Papers of the Amcrican Anthropological Association, no. 3 (Washington, D.C., 1992); Patricia B. Kwachka, ed., Perspectives on the Southeast: Linguistics. Archaeology, and Ethnohistory (Athens, Ga., 1994); Timothy R. Pauketat and Thomas E. Emerson, eds., Cahokia: Domination and Ideology in the Mississippian World (Lincoln, Neb., 1997); John F. Scarry, ed., Political Structure and (hange in the Prehistoric Southeastern United States (Gainesville, Fla., 1996); and Thomas E. Emerson, Cahokia and the Archaeology of Power (Tuscaloosa, Ala., 1997).

${ }^{15}$ Tom Hatley, The Dividing Parhs: Cherokees and South Carolinians Through the Era of Revolution (New York and Oxford, 1993), 10; and O'Brien, "Protecting Trade through War," 149-60.
} 
Franchimastabé (the same man who had led the Choctaw military force to Natchez in 1778), welcomed the Georgians and was glad to "hear a good talk from his old friends." 16 Coming on the heels of the previous summer's trade mission to Savannah-which Franchimastabé had organized-it appeared to the Choctaws that the Americans might actually fulfill their promises of trade goods. This perception was further confirmed when another American, trader John Woods, reached West Yazoo with an invitation from the United States government to meet during the coming winter. Understanding the potential for restoring the "play-off" system and the flow of merchandise, Franchimastabé and other chiefs seized the opportunity to establish relations with this third source of commodities. In the late eighteenth century Franchimastabé and other Choctaw chiefs used relations with European officials and traders to amass large reservoirs of reciprocal obligations by means of distributing manufactured goods. From the time of initial British occupation of West Florida in 1763, Franchimastabé earned payments in guns and other items by militarily supporting British aims in the South. These actions and his acquisition of goods pushed his status well beyond that of other chiefs. In 1784 Spain officially recognized Franchimastabé as the principal leader of the entire Choctaw western division. In the post-Revolutionary era, Franchimastabé and other chiefs viewed the new United States government as a source of economic, political, and even spiritual aggrandizement, not as a former enemy confronted on the field of battle. The Choctaws felt aloof from the conflict between the eastern seaboard colonies and Great Britain, telling the governor of Georgia, John Houston, in 1784 that "we have always Been friends to both the English and Americans long before the late Divisions between them and in the time of their Contest have never taken an Active part on Either side against the other." Having never attacked the United States, the unconquered Choctaws brought an elaborate and hopeful strategy to Hopewell that focused on establishing mutually beneficial trade relations with the new nation. ${ }^{17}$

it Nicholas Long Jr., William Davenport, and Nathaniel Christmas to Governor Samuel Elbert [of Georgia], September 13, 1785, in Edmund C. Burnett, comp., "Papers Relating to Bourbon County, Georgia, 1785-1786, [Part] II," American Historical Review, XV (January 1910), 337.

${ }^{7}$ Letter from the Choctaw Nation to [Governor of Georgia] John Houston, May 8, 1784, File II (Subjects: Indians), RG 4-2-46, Loc. 1543-01, box 74, folder 2 (Georgia Department of Archives and History. Atlanta) (quotation). All quotes by the Choctaws contained in this article were translated and transcribed by Euro-Americans and therefore should not be considered entirely literal statements. Nevertheless, the quotations selected should give the reader a reason- 
However, flushed with victory and a peace in Paris that ended the war but neglected Indian land claims, representatives from the Continental Congress asserted their right to dictate postwar realities to Indians. In the South, all of the larger Indian groups-the Cherokees, Creeks, Chickasaws, and Choctaws-had aided Great Britain's military efforts in some fashion. Thus, according to European definitions of warfare, those Indians "lost" the war when their ally surrendered at Yorktown. "The United States in these first treaties after the Revolutionary War," writes historian Francis Paul Prucha, "thought it was dealing with conquered tribes or nations," even though Indian peoples "had no idea that they were to be treated as conquered peoples." 18 The United States government built upon the treaty system established by Great Britain in more than a century of interacting with Indians. Initiating this strategy first in the Old Northwest through the treaties of Fort Stanwix (with the Iroquois in October 1784), Fort McIntosh (with the Delawares, Wyandots, and others in January 1785), and Fort Finney (with the Shawnees in January 1786), the United States adopted a policy of imposing terms upon Indians and seizing their lands where possible and desirable. Negotiations with Indians who lived south of the Ohio River, which began in the fall of 1785, also entailed a heavy-handed, though less land-hungry, approach on the part of the young government. ${ }^{19}$

Based upon its jurisdiction over foreign relations and its authority to make treaties and manage Indian affairs, in March 1785 the Continental Congress appointed commissioners to treat with the southern Indians. Of the original five commissioners, South Carolinian Andrew Pickens, Virginian Joseph Martin, and North Carolinian Benjamin Hawkins accepted their appointments and journeyed southward. The young United States found it harder to develop and implement a cohesive Indian policy in the South than in the North, partly

\footnotetext{
ably accurate idea of what the Choctaws were trying to say and accomplish. On Franchimastabé see O'Brien, "Choctaws in a Revolutionary Age," Chap. 5.

${ }^{18}$ Prucha, Great Father, I, 45; cf. his similar statement in Prucha, American Indian Treaties, 41.

${ }^{19}$ For summaries of post-Revolutionary relations hetween American Indians and the U.S. government see Colin G. Calloway, The American Revolution in Indian Country: Crisis and Diversity in Native American Communities (New York and Cambridge, Eng., 1995), esp. 272-91; Dorothy V. Jones, License for Empire: Colonialism by Treaty in Early Americu (Chicago and London. 1982), esp. 151-53; James H. Merrell, "Declarations of Independence: Indian-White Relations in the New Nation," in Jack P. Greene, ed., The American Revolution: Its Character und Limits (New York and London, 1987). 197-223; and Kenneth M. Morrison, "Native Americans and the American Revolution: Historic Stories and Shifting Frontier Conflict," in Frederick E. Hoxie, ed.. Indians in American Hislory: An Introduction (Wheeling, Ill., 1998), 87-104.
} 
because southern states opposed congressional control over Indian affairs. Virginia, North Carolina, Georgia, and South Carolina had all raised their own armies against Indian enemies (particularly the Cherokees) during the war, and the first three held claims, dating from their colonial charters, to Indian lands in the West. All of the southern states viewed it as their right to handle Indian affairs and manage their western land claims. The Continental Congress and its designated commissioners recognized southern sensitivity to Indian issues and invited each southern state to send its own representative to the proposed treaty councils. For example, William Blount of North Carolina, one of the principal participants in the Hopewell negotiations, joined the delegation specifically to ensure that his state's land claims in Cherokee territory remained valid. ${ }^{20}$

The American commissioners met first with the Creek Indians in late October 1785. Although Georgia protested Congress's authority to negotiate with the Creeks, resistance to subjugation on the part of Creek chiefs contributed more to the failure of their treaty with the United States than did Georgia's protests. The Creeks showed up at their appointed meeting place in Galphinton, Georgia, in insufficient numbers to represent the entire nation. Upper Creek leader Alexander McGillivray had prevented many Creek towns from sending representatives, and the congressional commissioners refused to negotiate a treaty with the few who did appear. McGillivray blocked American ambition whenever possible during the $1780 \mathrm{~s}$ in part because of Georgia's confiscation of his Tory father's land holdings and other property during the Revolution. In addition, McGillivray had a close business relationship with Panton, Leslie and Company, which was employed by Spain to conduct the deerskin trade with southern Indians. Nevertheless, agents from Georgia concluded a treaty with the small group of Creek Indians at Galphinton. Most other Creeks renounced the land cessions in this treaty and used it as an example of why Americans of all types could not be trusted. ${ }^{21}$

\footnotetext{
${ }^{20}$ Edmund Cody Burnett, The Continental Congress (New York, 1941), 628; Benjamin Hawkins, Andrew Pickens, and Jos[eph]. Martin, Commissioners, to Governor Patrick Henry of Virginia, June 10, 1785, in William P. Palmer, ed., Calendar of Virginia State Papers (11 vols.; Richmond, 1875-1893), IV, 33; and William Blount to Governor Richard Caswell fof North Carolina], July 3, 1785, William Blount Papers (McClung Historical Collection, Knox County Public Library System, Knoxville, Tennessee).

${ }^{21}$ Alexander McGillivray to Carlos Howard, August 11, 1790, in John Walton Caughey, McGillivray of the Creeks (Norman, Okla., 1938), 274-75; Mohr, Federal Indian Relations, 143-51; Prucha, American Indian Treaties, 60; Michael D. Green, "Alexander McGillivray," in R. David Edmunds, ed., American Indian Leaders: Studies in Diversity (Lincoln. Neb., and
} 
Cherokee Indians met first with representatives of the U.S. and North Carolina at Hopewell in late November 1785, and they offered little resistance to U.S. demands. The Cherokee Hopewell treaty, however, reflected more the American government's concern with a lasting peace and improved trade relations than with securing land cessions. Officials from North Carolina, like William Blount, opposed the Cherokee treaty from the outset because it failed to recognize the validity of prior Cherokee cessions to their state. North Carolina refused to adhere to the particulars of the Cherokee treaty, and, since the Continental Congress failed to hold a vote on the treaty, a new round of treaties commenced after adoption of the Constitution. ${ }^{22}$ Such jurisdictional conflicts between the states and the national government help to explain the lack of a cohesive Indian policy in the South prior to the establishment of the new federal government in 1789, but even afterwards, Georgians would challenge federal authority in Indian affairs and press their western land claims until 1802..$^{2.3}$

The Chickasaws had gained notoriety for their hostility to the new United States during the Revolutionary War. Allies of Britain throughout the eighteenth century, the Chickasaws responded to the threat of a Virginia wartime military expedition by warning Virginians to "[t]ake care that we dont serve you as we have served the French before with all their Indians, [and] send you back without your heads." ${ }^{24}$ The Chickasaws who met with the U.S. commissioners at Hopewell in early January 1786 (after the Choctaws had finished their treaty meeting) sought to establish trade relations with the United States, just as they had with Spain a year and a half earlier. The U.S.

London, 1980), 41-63; Thomas D. Watson, "Strivings for Sovereignty: Alexander McGillivray, Creek Warfare, and Diplomacy, 1783-1790," Florida Historical Quarterly, LVIII (April 1980), 400-414; Randolph C. Downes, "Creek-American Relations, 1782-1790," Georgia Historical Quarterly, XXI (June 1937), 142-84; Benjamin Hawkins and Andrew Pickens to Charles Thomson, January 1786, Henry Knox Papers (microfilm; Gilder Lehrman Collection. Pierpont Morgan I.ibrary, New York), reel 47: and Treaty of Galphinton. November 12, 1785, Knnx Papers, reel 18.

${ }^{22}$ Mohr, Federal Indian Relations, 147-51; Calloway, American Revolution in Indian Country, 208-9; and Jones, License for Empire, 134.

${ }^{23}$ North Carolina ceded its western claims to the federal government in 1789. See Mohr, Federal Indian Relations, 141-43; and Horsman, Expansion and American Indian Policy, 24. The Cherokee Hopewell treaty is reprinted in Charles J. Kappler, ed., Indian Affairs: Laws and Treaties: Vol. 2: Treaties (Washington, D.C., 1904), 8-11, and the treaty council in American State Papers: Documents, Legislative and Executive, of the Congress of the United States ... . March 3, 1789-March 3, 1815: Class II, Vol. IV: Indian Affairs (Washington, D.C., 1832), $40-43$.

${ }^{24}$ Calloway, American Revolution in Indian Country, 226. 
commissioners backed away from dictating terms to the Chickasaws, asking for no land cessions and promising a trading post at the Muscle Shoals on the Tennessee River, but they did insist that the Chickasaws accept the sovereignty of the United States "and of no other sovereign whatsoever." State opposition to the Chickasaw treaty was minimalother than a protest lodged by Blount-since their homeland in present northern Mississippi and southern Tennessee was distant from American settlements. ${ }^{25}$

These meetings with the southern Indians highlighted the disarray of U.S. Indian policy in the post-Revolutionary, pre-Constitution South, reflecting, in the words of historian Reginald Horsman, "a most confused and precarious state." 26 State goals, federal goals, individual goals, and Indian goals all contributed to the lack of a cohesive policy on the part of the United States. Within a year after the Hopewell treaties, the national government underwent, what historian Dorothy Jones called a "major policy retreat" whereby it recognized Indian occupation and title to lands in the West. ${ }^{27}$ The encounter with groups like the Choctaws increased American awareness that native powers operating in the Southwest met or exceeded American strength. However, the Hopewell treaty proceedings reveal that U.S. officials, while recognizing the tentative nature of their authority in the southern backcountry, nonetheless assumed an air of superiority, dictated terms, insisted on the inclusion of phraseology crafted before negotiations even took place, and probably deceived the Choctaws about the land cessions found in article three of the treaty document (which will be discussed below). Americans may have been conquerors in their own minds, but members of the Continental Congress and other American officials encountered, rather unexpectedly, the reality of Indian sovereignty and Indian control in vast regions east of the Mississippi River. Throughout the talks at Hopewell, Choctaw participants constantly reminded their hosts about Choctaw power and expectations.

Hopewell provided the first formal forum for the United States and the Choctaws to meet. Creating peaceful relations with a foreign

Calloway. American Revolution in Indian Country, 235 36; William L. Saunders and Walter Clark, eds., Colonial and State Records of North Carolina (25 vols.; Raleigh, N.C., 1886-1914), XVIII, 493-95; Prucha, American Indian Treaties, 63; the treaty in Kappler. ed., Indian Affairs, 14-16; and the treaty council in American State Papers, IV, 50-54.

${ }^{26}$ Horsman, Expansion and American Indian Palicy, 30.

${ }^{27}$ Jones. License for Empire. 147. 
people required the Choctaws to manipulate supernatural powers and employ political-religious specialists who could establish the sacred atmosphere necessary for incorporating strangers into the Choctaw kinship system. This requirement existed because there were essentially two types of people in Choctaw eyes: relatives and enemies. Turning enemies into kin was a serious business fraught with spiritual overtones, and accordingly, Franchimastabé appointed a chief named Taboca, who "had always been sent by the Nation as their representative in all their important Negotiations," to lead the expedition to Hopewell. ${ }^{28}$ Taboca and Franchimastabé had teamed up before to represent the Choctaws in meetings with foreigners: in 1784 Taboca had led the diplomatic mission to Savannah that Franchimastabé coordinated. The two possessed close marriage ties as well, for at least one of Taboca's daughters was also a niece of Franchimastabé ${ }^{29}$ Taboca's importance in diplomacy derived from his extensive command of spiritual power. His unique name designated "midday," "the [sun's] highest point," or "all sunshine," either connecting him directly with the energy of the sun, the most important manifestation of power in southeastern Indian cosmology, or with openness and honesty, for Choctaws believed that the sun observed their words and actions and punished those who committed transgressions. He held two additional titles, Hopaii Mataha and Mingo Hopaii, denoting "priest," "prophet," "war-prophet," or someone who could control events from afar. Taboca told the U.S. commissioners at Hopewell, "I am a headman in my Nation to receive and to give out talks [with foreigners]," and the interpreter for the Choctaws at Hopewell, John Pitchlynn, characterized Taboca as "the ablest speaker of all the chiefs." Taboca's presence thus ensured the safety of the mission and the likely success of the treaty meeting. ${ }^{30}$

Cognizant of the spiritual as well as physical dangers inherent in travel abroad, the Choctaw diplomatic mission to Hopewell traveled

${ }^{28}$ Martin journal, 64.

${ }^{24} \mathrm{O}^{+}$Brien, "Choctaws in a Revolutionary Age," $111-45,170-73$.

${ }^{30}$ Martin journal, 73, 64 (quotations). For more detail on Taboca as a political-religious specialist see O'Brien. "Choctaws in a Revolutionary Age," 1 I 1-45. On the translation of Taboca see Cyrus Byington, A Dictionary of the Choctaw Language, edited by John R. Swanton and Henry S. Halbert (Bureau of American Ethnology Bulletin 46, Washington. D.C., 1915), 336; and Horatio B. Cushman, History of the Choctaw, Chickasaw, and Natchez Indians (Stillwater, Oklat.. 1962), 47. On the translation of other titles see Byington, Dictionary, 165, 190, 525; Swanton, Source Material, 122-23; and James Adair, Adair's History of the American Indians (Johnson City. Tenn., 1930), 71. On the sun as an expression of power see John R. Swanton, "Sun Worship in the Southeast," American Anthropologist, XXX. new series (April-June 1928), 208-9; and Charles Hudson, The Southeastern Indians (Knoxville, Tenn., 1976), 126-27. 
slowly, probably to preserve a deliberate and ritualistic air. ${ }^{31}$ Native Americans in the Southeast and elsewhere customarily journeyed long distances from home to trade, fight, or meet with other people. Doing so, however, required adherence to strict rules governing proper behavior and the presence of proven spiritual leaders, like Taboca, who could ensure the group's success. Accompanying Taboca, and just as vital to the success of the treaty expedition, were ten women, several lower-ranked chiefs, and nearly a hundred warriors. Leaving their homeland in central Mississippi for Hopewell brought the Choctaw delegates into contact with potentially dangerous people, especially the Creek Indians, who had a history of warring against the Choctaws, and equally dangerous supernatural beings, such as the "Hoklonotéshe" who could "assume any shape he desires and is able to read men's thoughts." 32

Upon arriving on the treaty grounds at Hopewell on December 26, 1785 , after over two months of walking in the early winter cold, the Choctaws began trying to educate the American representatives about the correct way to construct a bond between two peoples. Trader John Woods escorted the Choctaws to Hopewell, and he sent a letter when the party was but a few days from the meeting site, warning the Americans of their imminent arrival. When they reached Hopewell, the Choctaws looked miserable and waited for the Americans to mollify their discomfort. Clothed in animal skins and appearing impoverished, they expected to be supplied with new garments by the people who had invited them to Hopewell and insisted that they journey so far. They wanted gifts of clothing, food, and other items from their hosts as a gesture of goodwill and honesty. As with many, if not all, American Indian groups, the Choctaws considered gifts fundamental to the establishment of a social environment in which peaceful relations could take place. The Americans did not understand Choctaw etiquette and were disappointed with the Indians' insistence on gifts, calling them "the greatest beggars, and the most indolent creatures we ever saw ...." Expectation of gifts is a pervasive feature of Native American diplomacy, and refusing to provide them threat-

\footnotetext{
${ }^{31}$ For other examples of Native American trade missions see Mary W. Helms, Ulysses' Sail: An Ethnographic Odyssey of Power, Knowledge, and Geographical Distance (Princeton, N.I., 1988), 84-85.

${ }^{32}$ Swanton, Source Material, 198 (quotation). The Crecks and Choctaws fought a protracted war from 1766 to 1777: see O'Brien. "Protecting Trade through War," 149-66.
} 
ened harmonious relations. ${ }^{33}$ The Choctaw delegates, perhaps aware of their host's dismay, explained that the Creek Indians had stolen their horses and supplies and declared that negotiations could not begin without proper clothing from the U.S. commissioners. Following the Choctaws' compelling - but maybe less than honest-explanation, the Americans agreed to provide the Choctaws with clothes and other supplies, including eighteen army coats, but they resented doing so, complaining that the Choctaws' "strong hankering for presents could not be abated . . ., 34

The U.S. commissioners opened official talks on December 30 with a speech calling for peace between the two peoples and for Choctaw acknowledgment of American sovereignty in the region. Before adjourning for the day (and again on January 2), the Americans attempted to demonstrate the size of United States territory, including the Choctaw homeland, on a map. Either the Choctaw representatives misunderstood the American claim to all land east of the Mississippi River or they intentionally feigned confusion. "[T]heir knowledge of maps was not equal by any means to the Cherokees," complained Joseph Martin, "and it was difficult to make them comprehend the extent of territory within the United States of America." Just as the tale of Creeks stealing Choctaw supplies persuaded the American commissioners to abide by Choctaw definitions of diplomatic protocol, the

'3.S. Commissioners [Benjamin Hawkins, Andrew Pickens, and Joseph Martin] to John Hancock [President of Congress], January 4, 1786, in Colin G. Calloway, ed, Early American Indian Documents: Treaties and Laws, 1607-1789: Vol. XVIII: Revolutiun and Confederation, Alden T. Vaughan, gen. ed. (Bethesda, Md., 1994), 415-16 (quotation on p. 416). See also Usner, Indians, Setrlers, and Slaves, 212; Daniel K. Richter, The Ordeal of the Longhouse: The Peoples of the Iroquois League in the Era of European Colonization (Chapel Hill and London, 1992), 47; Elizabeth Vibert. Traders' Tales: Narratives of Cultural Encounters in the Columbia Plateau, 1807-1846 (Norman, Okla., and London, 1997), 145-49; and Mary Black-Rogers, "Varieties of 'Starving': Semantics and Survival in the Subarctic Fur Trade, 1750-1850," Ethnohistory, XXXIII (Fall 1986), 367-70.

${ }^{34}$ U.S. Commissioners to John Hancock, January 4, 1786, in Calloway, ed., Early American Indian Documents, 416 (quotation). From at least November 4, 1785, the Choctaw mission waited among the Creck Indians before journeying all the way to Hopewell. Probably, they toured various Creek villages, reinforcing old ties and establishing new ones. See Luke Mann to the Governor of Georgia Samuel Elbert, November 4, 1785, in Hays, ed., Creek Indian Letters, Talks, and Treaties, I, 101: Martin journal, 56-58; and Benjamin Hawkins and Andrew Pickens to Charles Thomson. January 1786, Knox Papers, reel 47. The Choctaws returned to their homeland through Creek territory as well, something they likely would not have attempted (especially laden with new supplies from the Americans) if the Creeks had indeed stolen their horses and supplies, though it is possible that certain Creek towns disrupted the Choctaw delegation on their journey to Hopewell and that the Choctaws chose a different route home through different Creek villages. The Chickasaws met the Americans at Hopewell immediately following the Choctaws and presented themselves in the same impoverished situation-perhaps demonstrating a ploy common to southeastern Indian diplomacy. 
Choctaw's ignorance of maps permitted them to disregard another nation's claims to their lands. The Choctaw delegates probably wondered why the land where they lived, and for which no land cession had ever been negotiated, fell within the jurisdiction of the United States. Conversely, the Americans insisted on printed documents such as maps as the legitimate record and sought Choctaw adherence to the authority of these pieces of paper. Throughout the meeting, however, Choctaws reminded their hosts that they were in control of their own destiny and that diplomacy must proceed according to their rules and wishes, regardless of what a paper map might indicate. ${ }^{35}$

When their talks resumed on December 31, Choctaw speakers emphasized the importance of the weather. Although it mattered little, beyond basic comfort, to the Americans, for the Choctaws the weather during the talks was very significant. According to Choctaw belief, the sun observed their words and deeds and guaranteed that everyone spoke honestly. Talks conducted in cloudy conditions might result in dishonesty or in a lack of trust that could undermine the goal of creating kin out of strangers. The Choctaw chief Yockonahoma announced on the first day of talks that "this is a clear sunshiny day and I hope it will be emblematical of but future Happiness and that nothing will happen to cloud or obscure our Talks." Similarly, another chief, Mingohoopoie, noted three days later that "|t|his is a Clear and Sunshiny day on which we have met and it is to us as the promise of length of years." ${ }^{36}$ This feature of Choctaw diplomacy probably explains the three days during the conference when the Choctaws refused to negotiate: December 29, January 1, and January 4. Only when the sun shone did talks proceed.

Under a sunny sky on December 31, the Choctaw delegation began by excusing Franchimastabé's absence. The Continental Congress had sent Franchimastabé the original invitation to the Hopewell meeting, thinking that he ruled the Choctaws. A letter from Franchimastabé explained that he chose the members of the Choctaw mission and authorized Taboca to treat with the United States. Presumably, Franchimastabé declined attendance at Hopewell because he had received official recognition as the leading chief of the western division, in addition to medals, flags, clothing, and other merchandise, from Spain at the 1784 Mobile Conference. Conceivably, Choctaws chose

${ }^{35}$ Martin journal, 59-63, 75 (quotation).

${ }^{36}$ Ibid, 66, 81 (quotations). Spellings of Choctaw chiefs' names and titles, other than Franchimastabé and Taboca, are as found in Martin's journal. 
their representatives at Hopewell based on their not having attended the 1784 treaty negotiations with Spain, rather than because they were the principal leaders of their divisions. None of the Choctaw speakers from Hopewell appear in a detailed list of principal men recognized by Spain at the 1784 Mobile Treaty. ${ }^{37}$ What is clear is that the speakers at Hopewell did not reflect the highest ranking chiefs of the three divisions. Most of the Choctaw speakers expressed anxiety about their lack of high status. Yockonahoma claimed that Franchimastabé "ordered me to come but not to make the talk long." ${ }^{38}$

Yockehoopoie cautioned that "I am not a principal headman of our Nation but what I do here is valid." 39 Shinshomastabé similarly excused himself: "There are others to speak who have greater abilities than I have - and as I am a young hand I will not say anything more .. I am not a leading man of the Nation." ${ }^{, 40}$ Not all Choctaw speakers at Hopewell were novices in diplomacy, but the presence of so many lower-ranked chiefs playing a prominent role in the proceedings and their absence in the extant records of the 1784 treaty with Spain suggests that the Choctaws purposely avoided individual chiefs forming personal alliances with more than one Euro-American nation at a time.

This diplomatic principle caused Taboca to ceremonially disavow his allegiance with Spain. He had received a Spanish medal at Mobile just months before the Hopewell meeting, and other Choctaw speakers exposed his apparent conflict of interest. According to Martin, "[Taboca] was now ordered to be disgraced for his impudence before the Commissioners of the United States by making him speak last," normally the place of those with the lowest status. ${ }^{41}$ Nevertheless, Taboca performed an indispensable role in Choctaw diplomacy, making his presence essential to the success of the Hopewell conference and the Choctaw rituals performed there, and his attendance demonstrated the elasticity of diplomatic and cultural rules.

Taboca ended the first day of talks on December 31 in the mode of educator: "It is not usual to finish our talks in one day-I have brought up the headmen-they have talked - we will now shake hands with you and take these talks back to camp [for further deliberations]." ${ }^{42}$

\footnotetext{
${ }^{37}$ Martin journal, 64-67. The list of Choctaw men receiving recognition from Spain is in "Tratado de alianza entre España y los indios Chactas y Chicasas o Chicachas, 14 de Julio de 1784," in Serrano y Sanz, España y los Indios, 82-83.

${ }^{38}$ Martin journal, 65.

${ }^{14}$ Ibid., 81 .

${ }^{40}$ Ibid. . 69-70.

41 Ibid., 64.

42 Ibid, 73
} 
The treaty council proceeded two days later with the smoking of a calumet at the insistence of the Choctaws, another device meant to foster honesty and openness. Taboca and the other Choctaws assured the Americans that they were "the friends of white people whenever in their power," and that they would not let past alliances with Britain prevent the establishment of peaceful relations with the United States. ${ }^{43}$

West Yazoo's two leading chiefs, Franchimastabé and Taboca, supervised the outcome of this conference with the United States, but they organized the Hopewell mission with an eye toward representing all Choctaws. They selected headmen and warriors, and presumably the ten women, from each of the three Choctaw political divisions. Of the seven Choctaw men who spoke at Hopewell, Taboca and Yockonahoma represented the western division, Yockehoopoie, Mingohoopoie, and Tuscoonohopoia lived in the eastern division, Pooshemastubie resided in the Six Towns division, and Shinshomastabe came from either the western or Six Towns divisions. Pooshemastubie pointed out how closely allied his Six Towns division-the grouping of Choctaw villages closest to the Gulf Coast-was to the Spanish: "The part of our Nation where I live have never had any talks but from people on the Sea Shore (Spaniards) and when the chiefs of our nation [evidently Franchimastabé and Taboca] received your talks they sent for me because I was always firmly united with them." The speakers at Hopewell also demanded three American flags-one for each division - to demonstrate that all three divisions recognized the new relationship with the United States and enabling all three groupings to share any material largesse from the new nation. Despite apparent difficulties in finding eligible representatives from all three divisions, doing so ensured that an agreement with the Americans would benefit everyone and avoid conflict. ${ }^{44}$

Choctaws displayed a sophisticated understanding of the new political realities among Euro-Americans in post-Revolutionary North America. The United States comprised a completely new nation and people in Choctaw eyes. Although Taboca had led a Choctaw delegation to Georgia in 1784 and thus had met "Americans," the U.S. commissioners at Hopewell represented Americans of a different sort. Choctaws called the Americans present at Hopewell "Virginians,"

${ }^{43}$ Ibid., 74-76.

${ }^{44}$ Ibid., 71. See also U.S. Commissioners to John Hancock, January 4, 1786, in Calloway, ed., Early American Indian Documents, 416. 
which Joseph Martin explained was "the term they use to express the citizens of the United States." 45 These "Virginians" may have spoken English, but Choctaws differentiated them from the British or from those Americans utilizing a state identity, such as the Georgians. Choctaws recognized political identities readily and classified peoples according to the manner that such foreigners described themselves. Thus, Yockonahoma, who surely had encountered English-speaking persons before 1786, could say to the Americans at Hopewell: "I have never heard of you White People and our forefathers may have heard of you but I never saw you till now and I never heard that [our forefathers] ever did see you." ${ }^{46}$

Of course, very few Americans-and certainly not the delegates sent by the Continental Congress to Hopewell-knew much about the Choctaws either. They knew only that Britain served as the Choctaws' closest European ally since the early 1760 s and that Spain had signed a treaty with these Indians in 1784 . Consequently, they met with the Choctaws in the manner that an immigrant approaches his neighbors after moving into a new home. Civility and decorum characterized all the speeches and public actions undertaken by Pickens, Hawkins, and Martin at the treaty negotiations. They especially wanted to impress upon the Choctaws and other Indians "the humane views of Congress towards all the tribes of Indians within the United States of America." Although they detested certain Choctaw rituals, actions, and words used at the meeting, they only expressed those thoughts—-so far as we know-in private correspondence. Martin took pain to write down what the two sides said to each other and to describe in detail the Choctaw rituals, and Hawkins later transcribed and edited Martin's journal, which suggests that the Americans wanted a detailed record of the proceeding to educate other U.S. officials about this unfamiliar group of American Indians and to demonstrate their fairness and honesty in conversing with the Choctaws. Despite their professional behavior towards the Choctaws, the American delegates found little to praise and much to condemn when describing these "honest, simple" people who were still "the most indolent creatures we ever saw." 47

Lack of familiarity rarely breeds tolerance and appreciation. American officials held pre-conceived and unflattering notions about

\footnotetext{
${ }^{45}$ Martin journal, 75.

${ }^{46}$ Ibid. . 79-80.

${ }^{47}$ U.S. Commissioners to John Hancock, January 4, 1786, in Calloway, ed., Early American Indian Documents, 416 .
} 
who Indians were and what they were like, and these images stayed in the minds of the commissioners as they negotiated with the Choctaws. Revealing their ignorance of the Choctaws' mores, the Americans found their "passion for gambling and drinking is very great; we have had instances of their selling blankets at a pint of rum each, and gambling them away, when they had no prospect of replacing them." Choctaws and other southeastern Indians frequently wagered goodsespecially European manufactured items - at diplomatic meetings and at celebratory activities such as their ball games. Gambling served to redistribute valuable goods throughout the confederacy, and Choctaws viewed it as a perfectly acceptable way to exchange an item they had for something they wanted. Notwithstanding their barely hidden ethnocentrism, the Americans tolerated some Choctaw customs-at least superficially-in their attempt to construct genuine bonds between the two societies. ${ }^{48}$

Initiating relations with a hitherto unknown polity required an elaborate collection of rituals that created a sacred atmosphere for the Choctaws to convert foreigners into fictive kin. When the sun reached its highest point in the sky on January 3 , the day the treaty was signed, six Choctaws covered themselves in white clay, the color of peace and openness among southeastern Indians, and led the others in performing a series of formal ceremonies, including the eagle tail dance. Amid music, singing, and dancing, the Choctaw chiefs set up a twelve-footlong white pole, establishing a sacred area in front of the bower constructed for the treaty meetings. Yockonahoma explained the pole's purpose: "I have set up a white pole-our token of peace-it is but a short pole but the peace will be long and lasting." Three chiefs carried shorter poles with deerskins attached to the tops, while two others carried white calumet pipes and fire to light the pipes. The 121 other Choctaw men and women wore the clothes that the commissioners had given them a few days earlier and marched to the area where the larger pole stood. The congressional representatives lined up across from the Choctaws and distributed more presents of clothing and pipes. Taboca

${ }^{48}$ Ibid, 416 (quotation). On southeastern Indian gambling see Hudson, Southeastern Indians, 418, 423; and Swanton, Source Material, 140, 155. On the importance to American government officials of civility when dealing with Indians in the early republic period see Andrew R. I. Cayton, "Noble Actors' upon 'the Theatre of Honour': Power and Civility in the Treaty of Greenville," in Cayton and Teute, eds., Contact Points, 235 69. On American images and perceptions of Indians see Robert F. Berkhofer Jr., The White Man's Indian: Images of the American Indian from Columbus to the Present (New York, 1978), esp. 134-45. 
then laid at the base of the pole sacred fire carried all the way from the Choctaw homeland and lifted hot coals from the American fire to take home. In this way, people of two fires-or two distinct families merged together. A warrior told his war exploits and then the chiefs on one side and commissioners on the other joined hands, exchanged lighted pipes, and walked under the bower to the meeting table. ${ }^{49}$

Under the bower, "the master of ceremonies Taboca applied the eagle tail to the breasts of the Commissioners, the agent, and some respectable Gentlemen, then covered the seat of the Commissioners with two [white] deerskins and laid them under their feet." Taboca explained that "these feathers of the Eagle tail we always hold when we make peace." ${ }^{50}$ Bald eagles appear repeatedly in southeastern Indian iconography as a symbol of peace. Eagles represented the Upper World of the sun because they traveled between the earth and sky, thus making their feathers appropriate symbols of honesty and openness since Choctaws thought that the sun observed their actions and punished those who spoke falsely or acted deceitfully. ${ }^{51}$ Placing prominent foreigners in a seat covered with white deerskins during diplomacy was a demonstration of tremendous respect. "The [southeastern] Indians cannot shew greater honour to the greatest potentate on earth, than to place him in the white seat ... and dance before him with the eagles tails," observed British trader James Adair in the mid-eighteenth century. ${ }^{52}$

In addition to ceremonies with eagles' tails and white deerskins, smoking the calumet sanctified agreements between peoples. Calumets carried inherent spiritual power and guaranteed that a treaty was sacred because it was sealed by the smoking of the pipe. An eighteenthcentury French eyewitness of other Choctaw diplomatic meetings clarified the pipe's role: "When they have concluded the peace the master of ceremonies lights this calumet and has all those who are in the assembly smoke two or three whiffs," after which "the treaty is [considered to be] concluded and inviolable." The smoke metaphorically carried everyone's words upward to the sky and sun, ensuring honesty and commitment to the agreements reached during the meeting. The host then gave the leading chief of the foreign group the calumet,

\footnotetext{
${ }^{44}$ Martin journal, 76-82 (quotation on p. 80). On the significance of the color white see Hudson, Southeastern Indians, 132.

${ }^{50}$ Martin journal, 79, 82 .

51 Adair, History of the American Indians, 32; and Hudson, Southeastern Indians, 163-65.

${ }^{52}$ Adair, History of the American Indians, 176-77; spellings are as contained in the original document.
} 
"which is a hostage of their good faith, and the fidelity with which they wish to observe the articles on which they have agreed." 53

The Hopewell Treaty with the United States involved far more than a simple agreement. Because the Choctaws had no prior relationship with the Americans, one more crucial element was needed for them to complete the alliance rituals. After the women painted themselves with white clay, sang and danced as part of the eagle tail dance, and exchanged gifts with the Americans, Taboca informed the commissioners: "You see our women are painted white - an emblem of peace and of their hopes of being able to raise up their Children in peace." The final ritual on January 3 required the women to approach the U.S. commissioners and embrace them. ${ }^{54}$ The embrace of the women almost certainly meant that they metaphorically adopted the Americans into their lineages. The ten women adopted the American commissioners as fictive kin, something only they could do in Choctaw matrilineal society. Although there are few descriptions of the role of eighteenthcentury Choctaw women in diplomatic missions as detailed as this one, it seems likely that women always accompanied men to diplomatic meetings and participated in the rituals there. Their absence from many other records of Choctaw diplomacy with Europeans likely reflects more the Euro-American emphasis on men as political leaders and negotiators than Choctaw realities. ${ }^{55}$ In the absence of the bonds of kinship, Choctaws did not know how to relate to other people; for them, a person who had no place in the kinship system stood outside the boundaries of normal human interaction. Adoption rituals and the mediation of women, therefore, were essential to conducting diplomacy according to Choctaw rules. After the women's embrace of the commissioners, the music stopped and the participants took their seats to continue talks.

This extraordinary day ended in the same instructive tone with which it began. Yockehoopoie reminded the Americans that the peace just established "is not for ourselves alone, we are now making peace

\footnotetext{
5.7 John R, Swanton, "An Early Account of the Choctuw Indians," American Anthropological Association Memoirs, V (1918), 67, also printed in John H. Peterson Jr., ed., A Choctaw Source Book (New York, 1985). Swanton dated this anonymous document to 1755. See also Robert A. Williams Jr., Linking Arms Together: American Indian Treaty Visions of Law and Peace, 16001800 (New York and Oxford, 1997), esp. 44, 47, 75-76; and Robert L. Hall, "Calumet Ceremonialism, Mourning Ritual, and Mechanisms of Inter-Tribal Trade," in Daniel W. Ingersoll Jr. and Gordon Bronitsky, eds., Mirror and Metaphor: Material and Social Constructions of Reality (Lanham, Md., and London, 1987), $30-32$.

${ }^{54}$ Martin journal, 82 (quotation), 79.

${ }^{55}$ See O'Brien, "Choctaws in a Revolutionary Age," Chap. 4.
} 
for the people of all our respective nations and their posterity." 56 Taboca added that " $[t]$ he object of the Great men who Employed you and the Great man who sent us is accomplished as with our mouths we have locked our hands." ${ }^{57}$ In Choctaw eyes, United States citizens and the Choctaw people now regarded one another as fictive kin. Having completed that vital task, the Choctaws adjourned for the day and rested comfortably knowing that subsequent days would bring the negotiations around to the issue they most wanted to discuss: trade. ${ }^{58}$

Two days later, the U.S. commissioners presented the written treaty to the Choctaws. Believing that the Choctaw delegates "comprehended the whole perfectly," the Americans declared the Choctaws "satisfied with every part" of the treaty. ${ }^{59}$ The Choctaws and Americans signed two copies of the treaty, one for each party. After the treaty was signed, the Americans considered their business over and looked forward to their impending meeting with the Chickasaws. The Choctaw delegates viewed the signing of the treaty as less climactic, regarding it instead as simply the one major ritual that the Americans required. Yockonahoma suggested that he was not even sure what had been agreed to when he said that he "shall take John Pitchlynn the interpreter with me [so] he can tell us all our talks over again." According to the Choctaws, the negotiations had just begun. The treaty established peaceful relations between fictive kin, but "we will after this day talk of something else." 60

That "something else" was trade, which was the real motive underlying the Choctaws' arduous journey to Hopewell. Although "we have ended all peace talks," Mingohoopoie explained that "our Nation is much in Want of Match Coats powder and lead and I wish they could be supplied by your traders.... I hope the [Choctaw] Nation will be supported with necessaries as early as possible. We are much in want of guns [,] amunition / sic/ and clothing." He further insisted that trade goods formed a basic part of diplomacy between Choctaws and whites:

\footnotetext{
${ }^{56}$ Martin journal, $80-81$

${ }_{57}^{57}$ Martin journal, 82.

${ }^{58}$ For further analysis of the purpose of establishing kin-like associations see Mary W. Helms, Craft and the Kingly Ideal: Art, Trade, and Power (Austin, Tex., 1993), 190; and William N. Fenton, "Structure, Continuity, and Change in the Process of Iroquois Treaty Making," in Francis Jennings and William Fenton, eds., The History and Culture of Iroquois Diplomacy: An Inter disciplinary Guide to the Treaties of the Six Nations and Their League (Syracuse, N.Y., 1985), 12-14.

${ }^{59}$ Martin journal, 84.

${ }^{60}$ Ihid., 86 (first quotation). 85 (second quotation),
} 
"It was formerly a custom when I was at peace talks for the Indians to receive such guns as the white people made to carry to our nation." ${ }^{\text {"61 }}$ Taboca reiterated this sentiment, declaring that "Our Nation is much in want of clothing, arms, \& ammunition and it is my desire that Capt. John Woods should be in a situation to see that our situation is remembered." John Woods had escorted the Choctaws to Hopewell, and they expected him to serve as the official American representative to their towns. A prominent feature of eighteenth-century Choctaw diplomacy, the exchange of ambassadors gave Choctaw chiefs a person to whom they could appeal in order to ensure a consistent and plentiful supply of trade goods. Taboca, who referred to himself as the "Great Traveller," offered in turn to visit the United States Congress, thus demonstrating Choctaw willingness to maintain direct contact with the American government now that kin relations had been established between the two peoples. ${ }^{62}$ For the Choctaws, trade would provide an equal basis for their future interactions with the United States.

In addition to trade, Mingohoopoie focused on two other issues about which he cared deeply. Article 1 of the Hopewell treaty called on the Choctaws to release any prisoners or African slaves taken during the Revolutionary War. Since the Choctaws held no such prisoners, this article's inclusion suggests that the Americans arrived at Hopewell with a document already prepared for the signatures of Britain's former Native American allies, and thus it should come as little surprise that Choctaw attempts to actually negotiate would meet with frustration. Nevertheless, Mingohoopoie called on the Americans to abide by the first article, protesting that some Americans had kidnapped one of his wives and a niece when they were visiting a Creek town. He asked the commissioners to look into the matter and return the women if possible. Articles 4, 5, and 6 of the treaty covered persons committing crimes within Choctaw territory, specifying that Americans who trespassed on Choctaw lands forfeited their right of protection from the U.S. government; that Indian or white criminals who harmed Americans and took refuge among the Indians were to be turned over to the United States for punishment; and finally that the United States would punish any of its citizens who committed crimes against the

${ }^{61}$ Ibid., 87-88.

${ }^{62} \mathrm{Ibid}$, 90. On Choctaw exchanges of permanent ambassadors with other nations see Patricia Galloway, "The Chief Who is Your Father': Choctaw and French Views of the Diplomatic Relation," in Wood, Waselkov, and Hatley, eds., Powhatan's Mantle, 254-78. 
Choctaws. Mingohoopoie responded favorably to these articles and revealed a perceptive understanding of possible conflicts between Choctaws and Euro-Americans that had existed from the earliest days of contact:

The article respecting the mode of punishment of villains \& I am exceedingly pleased with and it will prevent the commission of evil. [Y]ou are not the first men I have treated with on this subject. [F]ormerly when I treated with the British we did something like it and I always punished accordingly thereto. We here are headmen and it is as impossible for us to be responsible for all the warriors as it is for you to become responsible for the disorderly people of your nation. We have bad people in our nation and there are good and bad of all nations. ... I have received your talks and I love your talks and if there should he any violation of the articles we will punish immediately in the Nation. ${ }^{63}$

The Choctaw delegates thus agreed with certain aspects of the written and signed treaty, but they strongly disagreed with the second and third articles. Article 2 placed the Choctaws "under the protection of the United States of America, and of no other sovereign whosoever." From the Choctaw perspective, the full implications of such a stipulation were unthinkable; they intended to preserve their sovereignty and maintain relations with whomever they chose. Just one year later, an emissary of the Spanish government, Juan de la Villebeuvre, visited Franchinmastabé at West Yazoo and reaffirmed the Choctaw-Spanish alliance of $1784 .{ }^{65}$ In the meantime, the Choctaws continued to welcome sporadic traders and agents from the southern states, such as Benjamin James from Georgia. ${ }^{66}$ While the Choctaws failed to protest Article 2 directly, they probably interpreted it in light of reciprocal kinship and trade relations between the two nations rather than as an acknowledgment of U.S. jurisdiction over Choctaw territories and peoples. Otherwise, their subsequent unilateral actions to establish relations with as many Euro-American polities as possible would make little sense.

\footnotetext{
${ }^{67}$ Martin journal, 89 12).

${ }^{64}$ Choctaw Hopewell treaty of 1786, repr. in Kappler, Indian Affairs, 11-14 (quotation on p.

${ }^{65}$ Manuel Serrano y Sanz, Spain and the Cheroke'e and Choctaw Indians in the Second Half of the Eighteenth Century, translated by Samuel Dorris Dickinson (Idabel, Okla, 1995), 26-28; and Reply of Franchimastabé after the speech of Captain Don Juan de Villebeuvre, November 1 . 1787. Mississippi Provincial Archives: Spanish Dominion (Mississippi Department of Archives and History, Jackson) (hereinafter cited as MPASD), Vol. III, reel A521.

${ }^{66}$ On James's appointment as Georgia agent to the Choctaws see Mohr, Federal-Indian Relations, 154-55; "An Ordinance for Appointing Agents to Reside in the Indian Nations [1786]," in Allen D. Candler, ed., The Colonial Records of the State of Georgia (Atlanta, Ga., 1911), XIX, Part 2, 532-33; and Colonel Joseph Martin to Governor [Edmund] Randolph of Virginia, March 25, 1787, in Palmer, ed, Calendar of Virginia State Papers, IV, 261 (Martin mistakenly refers to James as "Jones").
} 
It is doubtful that anyone explained the precise implications of Article 3 to the Choctaw delegation during the treaty negotiations. Despite a stated goal on the part of the United States not to want "more of your lands or anything else which belongs to you," Article 3 of the Choctaw Hopewell Treaty called for the establishment of three trading posts, six square miles each, within Choctaw territory. Furthermore, the United States claimed sole right to choose the locations of these posts. ${ }^{67} \mathrm{Had}$ the Choctaws known that the United States intended to build three trading posts within their territory, it would not have been necessary to request traders and insist on supplies of trade goods. However, it was the fine print of Article 3, in which these American trading posts were said to consist of six square miles each, that caused an uproar among the Choctaws. After learning of this provision upon the delegation's return, Franchimastabé offered to send his warriors to fight with the Creeks against the Americans - a clear indication that he strongly rejected the notion that the Choctaws had ceded any of their lands to the United States. He also employed a trader among the Choctaws to write to the Cherokees' American agent chiding United States representatives for not establishing a consistent trade (without occupying Choctaw lands) and warning them about possible attacks from his warriors. ${ }^{68}$ Other Choctaw chiefs further condemned American actions at Hopewell in meetings with Spanish officials in 1787 and 1788. Yockonahoma, one of the principal speakers at the Hopewell negotiations, eloquently argued the Choctaw position and defended his actions:

\footnotetext{
${ }^{67}$ Martin journal, 6.3 (quotation). Article 3 of the Choctaw Hopewell treaty, as reprinted in Kappler, Indian Affairs, 12, reads as follows: "The boundary of the lands hereby allotted to the Choctaw nation to live and hunt on, within the limits of the United States of America, is and shall be the following, viz. Beginning at a point on the thirty-first degree of north latitude, where the Fastern boundary of the Natches district shall touch the same; thence east along the said thirty. first degree of north latitude, being the southern boundary of the United States of America, until it shall strike the eastern boundary of the lands on which the Indians of the said nation did live and hunt on the twenty-ninth of November, one thousand seven hundred and eighty-two, while they were under the protection of the King of Great-Britain; thence northerly along the said eastern boundary, until it shall meet the northern boundary of the said lands; thence westerly along the said northerly boundary, until it shall meet the western boundary thereof; thenee southerly along the same to the beginning: saving and reserving for the establishment of trading posts, three tracts or parcels of land of six miles square each, at such places as the United [States] in Congress assembled shall think proper; which posts, and the lands annexed to them, shall be to the use and under the government of the United States of America." The treaty is also reprinted in Fredrick E. Hosen, ed., Rifle, Blanket and Kettle: Selected Indian Treaties and Laws (Jefferson, N.C., and London, 1985), 29-32; and Calloway, ed., Early American Indian Documents, 413-15.

ths Alexander McGillivray to Estevan Miró, May 1, 1786, in D. C. Corbitt and Roberta Corbitt, trans, and eds., "Papers from the Spanish Archives Relating to Tennessee and the Old Southwest. 1783-1800," East Tennessee Historical Society Publications, X (1938), 134-35.
} 
You, my father, have reproached me several times for having gone to the Americans. That is correct, 1 have, but without intending to bring them into the nation, or to give them lands, like they say. It simply is poverty. As all red men are poor and do not know how to make anything, they are obliged to go see the white nations that make everything, in order that they may give them presents, and we went, believing that we would receive them. They began by asking us for lands, to which we said that we were not authorized by the nation to give lands to anyone. Nevertheless, they drew up a document, without telling us what it contained, and we thought it was for the purpose of giving us presents. They had us make some marks on it without our knowing what we were doing. Afterward they told us what it was. Then I seized the paper and I burned it. After this they had us drink strong water, or fire water, which intoxicated us, and when they saw us in this condition, they made us again make marks on the paper. ${ }^{69}$

Six square miles multiplied by three, or 11,520 acres, may seem diminutive from the standpoint of the eventual Indian land cessions to the United States, but Choctaws perceived a potential conflict if the United States ever sought to occupy the three areas of their choosing. Although Choctaws wanted traders to visit their villages, they refused to accept permanent settlers with the livestock and large-scale agriculture that inevitably accompanied the construction of trading posts. Just a few years later, the Spanish governor of Natchez, Manuel Gayoso de Lemos, confronted this problem when construction of a fort, post, and outlying buildings began at Nogales along the Mississippi River (present-day Vicksburg), which was within Choctaw territory. After the conclusion of the Revolution, Americans had flooded into Spanishcontrolled lands around Natchez along the boundary with the Choctaws, and now they began moving to Nogales as well. Some of these newcomers killed game animals in Choctaw hunting lands, stole horses within the confederacy, traded large quantities of alcohol to Choctaw warriors, and otherwise seriously strained constructive intercultural relations and local social control. Choctaw warriors and chiefs, especially Franchimastabé and Taboca, vehemently opposed the Nogales construction, and Gayoso spent two years attempting to placate them until the issue was finally settled. The Choctaws found it almost impossible to tolerate Americans living among them unless they were traders living in Choctaw villages, married to Choctaw women, and working under the purview of chiefs. ${ }^{70}$ Such difficulties with

${ }^{64}$ Speech of Yagane-huma (Yockonahoma) to Governor Estevan Miro, January 3, 1788, in Scrrano y Sanz, Spain and the Cherokee and Choctaw Indians, 30. See also John Pittslaw to Captain William Davenport, September 5, 1786, in Hays, ed., Creek Indian Letters, Talks, and Treaties, 1, 136.

${ }^{70}$ Documentation on the Nogales affair is extensive; the following works provide an introduction into the diplomatic wrangling that took place. Saruh J. Banks and Charles A. Weeks, Mississippi's Spanish Heritage: Selected Writings, 1492-1798, edited by Caroline S. Kelly 
permanent white settlements caused the Choctaws to agree with the Chickasaw desire for a trade store on the Muscle Shoals of the Tennessee River, still accessible to but outside the territory of both groups.

As Yockonahoma admitted in the passage quoted above, the Choctaws drank alcohol provided to them by the Americans throughout the meeting at Hopewell (and the U.S. commissioners complained about their crude behavior when drunk), but it is not at all clear that they were inebriated at the time of the treaty signing; no such references exist in the proceedings as recorded by Joseph Martin. Many Choctaws blamed interpreter John Pitchlynn's supposed illiteracy and his inability to read Article 3 for their ignorance of the land cessions. That would mean that the U.S. delegates failed to verbally explain Article 3, something they explicitly denied in their descriptions of the negotiations. However, Pitchlynn was not illiterate, at least not in later life. Interpreters between American Indians and Euro-Americans, as James Merrell has recently demonstrated, brought their own fallibilities and motivations to treaty councils and often caused the imperfect communications that developed there. Pitchlynn's qualifications seemed adequate enough: his trader father had introduced him to the Choctaws as a young boy, and he was raised among them, prospering materially in the confederacy and eventually taking a Choctaw wife by whom he fathered several children. As the U.S. commissioners at Hopewell noted of Pitchlynn, "[H]e is a very honest sober young man, and has lived twelve years in the nation and is much respected by the Chiefs as an Interpreter." It is impossible to ascertain whether Pitchlynn misled the Choctaw delegation at Hopewell (either through intention or incompetence), but if the meaning of Article 3 became lost in translation, then he certainly played a role in that confusion. ${ }^{71}$

(Jackson, Miss., 1992), 112-80; Christopher J. Malloy and Charles A. Weeks, eds., "Shuttle Diplomacy, Eighteenth-Century Style: Stephen Minor's First Mission to the Choctaws and Journal, May-June, 1791," Journal of Mississippi History, LV (February 1993), 31-51; and Fdward Hunter Ross and Dawson A. Phelps, eds., "A Journey Over the Natchez Trace in 1792: A Document from the Archives of Spain," Journul of Mississippi History, XV (Octoher 1953), 252-73. For Choctaw and Chickasaw efforts to have at trading post established at the Muscle Shoals see "A Talk for Colo[nel] Joseph Martin-From Piomingo, One of the Chiefs of that Trihe," Fehruary 15, 1787; and Colonel Arthur Camphell to Governor Edmund Randolph, April 15, 1787, both in Palmer, ed., Calendar of Virginia State Papers, IV, 241-42, 268.

${ }^{71}$ U.S. Commissioners to John Hancock, January 4, 1786, in Calloway, ed., Early American Indian Documents, 416 (quotation). On Pitchlynn's early life see Baird, Peter Pitchlynn, 5-8: see also Merrell, Into the American Woods, 210-15. On Pitchlynn's supposed illiteracy see McGillivray to Miró, May 1, 1786, in Corbitt and Corbitt, trans, and eds., "Papers from the Spanish Archives," 135. 
Yockonahoma had denied that the Choctaws ceded any lands at Hopewell, telling Spanish agents in January 1788 that the delegation at Hopewell did not have the authority to grant lands. ${ }^{72}$ That contention seems confirmed by the generally low-ranking status of most of the Choctaw chiefs at Hopewell, as well as the fact that they only partially represented each of the three divisions. The Americans, Spanish governor Esteban Miró insisted, "certainly know that the cited chiefs did not go to [Hopewell] on behalf of the entire nation, because the great chiefs had not convened in order to send them, and therefore they did not have the necessary authority to grant lands and make treaties." Miró also alluded to the divergence of views between the Americans and the Choctaws about what constituted a treaty; the Americans "had all [the Choctaw speakers at Hopewell] make a mark on the paper, which among the whites gives full authority to a treaty."73

Despite the controversy over Article 3, U.S. officials, especially General Henry Knox (who was appointed Secretary of War in 1789), emphasized all of the articles - and Choctaw agreement with themwhen explaining the importance of the Choctaw Hopewell Treaty in following years. In 1790 Knox recommended that the U.S. Senate further extend trade to the Chickasaws and Choctaws in order to counter the anti-American actions of the Creek Indians and the machinations of the Spanish; their allegiance, he said, should be pursued "agreeably to the Treaty of Hopewell." Around the same time, President George Washington called on American citizens to abide by the principles of the Hopewell treaty in dealings with the Choctaws and Chickasaws. Conveniently unaware of Choctaw objections to key portions of the written treaty, for years afterward American officials continued to issue misleading pronouncements that took for granted a decisive acceptance of the treaty's terms by both parties to it. ${ }^{74}$

The U.S. government also paid little attention to the specific Choctaw demands made at Hopewell. For example, they responded negatively to the Choctaw request for an American representative to

\footnotetext{
"Speech of Yagane-huma (Yockonahoma) to Governor Estevan Miró, January 3, 1788, in Serrano y Sanz, Spain and the Cherokee and Choctaw Indians, 30.

${ }^{73}$ Serrano y Sanz, Spain and the Cherokee and Choctaw Indians, 27.

${ }^{74}$ The treaty was entered into the journals of the Continental Congress on $A$ pril 16, 1786, and printed in the Philadelphia Pennsylvania Gazette on May 9, 1786. See also Henry Knox to the President of the United States, July 7, 1789. The New American State Papers: Indian Affairs: Southeast (Wilmington, Del., 1972), V1, 59-60; U.S. Commissioners to Choctaw Nation, September 13, 1789, in The Papers of Panton, Leslie and Company (microtilm; Woodbridge, Conn., 1986), reel 5, 595-96: Recommendations to the Senate, April 1, 1790, Knox Papers, reel 26: and "By the President of the United States of America. A Proclamation," n.d., Knox Papers, reel 53.
} 
live among them. No official agent of the federal government would live among the Choctaws for another decade. John Woods, who owned property around Natchez and had escorted Taboca and other Choctaw negotiators to Savannah, Hopewell, Philadelphia, and New York in the mid-1780s, lost his bid to gain authorization from the Continental Congress to be the official Indian agent to the Choctaws. Pickens, Hawkins, and Martin had questioned Woods's loyalties at Hopewell, calling him "a man of some enterprise and ability, but much addicted to strong drink. He came in with the Indians, and has been at much trouble |drinking| with them." 75

The U.S. commissioners at Hopewell tried to discourage Taboca from visiting Congress, but he journeyed to Philadelphia and New York anyway, arriving during the busy Constitutional Convention summer of 1787. Accompanied by a Choctaw warrior, a Chickasaw chief named Piamingo, and his wife, Taboca met with Benjamin Franklin, Henry Knox, George Washington, and other American officials before returning home by boat down the Ohio and Mississippi Rivers. ${ }^{76}$ Although he did convey the specific request for the establishment of a U.S. trading post at the Muscle Shoals on the Tennessee River, Taboca was interested in more than material benefits from his contact with the United States. His prestige and authority within Choctaw society reached new heights as he demonstrated his command over spiritual forces by traveling to distant lands and meeting foreign

\footnotetext{
${ }^{75}$ U.S. Commissioners to John Hancock, January 4, 1786, in Calloway, ed., Early American Indian Documents, 416 (quotation). See also May Wilson McBee, comp., The Natchez Court Records, 1767-1805: Abstracts of Early Records (Ann Arbor. Mich., 1953), 11, 164-67; Thomas P. Abernethy, The South in the New Nation, 1789-1819 (Baton Rouge, 1961), 76; Joseph Martin to Gov. Edmund Randolph of Virginia, March 16, 1787, in Palmer, ed., Calendar of Virginia State Papers, IV, 256; William Blount to John Gray Blount, July 19, 1787, in Burnett, ed, Letters of Members of the Continental Congress, VIII, 624; and John Woods to C. Griffin, February 21, 1788, and May 10, 1788, in Papers of the Continental Congress, 1774-1789 (microfilm; Washington, D.C., 1959), M-247, reel 56, vol. 8, item 42, pp. 402, 406.

it On Taboca's trip see Governor John Sevier [of Tennessee] to Governor George Matthews [of Georgia]. March 3, 1787, in J. G. M. Ramsey, The Annals of Tennessee to the End of the Eighteenth Century (Charleston, S.C.., 1853; repr., Knoxville, Tenn., 1967), 385; Colonel Arthur Campbell to Governor Edmund Randolph [of Virginia], March 9, 1787, and April 15, 1787; and "John Woods, Indian Interpreter," May 25, 1787, all in Palmer, ed., Calendar of Virginia State Papers, IV, 254, 268, 290; Henry Knox to "Chamby" [Chickasaw Chief]. June 27, 1787; and Knox to Frenchemastubic /sic/, June 27, 1787, both in Josiah Harmar Papers (William L. Clements Library, University of Michigan, Ann Arbor); "Choctaw Chief [Taboca] to Benjamin Franklin, June 19, 1787" (American Philosophical Society Library, Philadelphia, Pennsylvania); William Blount to John Gray Blount, July 19, 1787, in Edmund C. Burnet,, ed,, Letters of Members of the Continental Congress (8 vols.; Washington, D.C., 1921-1936), VIII, 624; Carlos de Grand-Pré to Fstevan Miró, Octoher 26, 1787, in Lawrence Kinnaird, ed., Spain in the Mississippi Valley, $1765-1794$ (Vols. II-IV of the Annual Report of the American Historical Association for the Year 1945, Washington, D.C., 1946), III, 236-37; and Alexander Fraser to Miró. April 15, 1788, East Tennessee Historical Society Publications, XIV (1942), 99.
} 
people. The Choctaws, like other cultures, accorded special status to those who gathered knowledge of foreign places and foreign people. Travel beyond the bounds of Choctaw civilized society carried mystical significance and designated one as a spiritual specialist. Years after Hopewell, Taboca would continue to display the tools of his power, all of which were based on the accumulation of esoteric knowledge from foreign travel. When the Spanish government official Stephen Minor paid the venerable chief a visit outside West Yazoo in 1792, Taboca "took out a small box in which he had his Papers and told me to read them all. I examined them and found an English Patent, and another in Spanish, a letter from an English delegate and another from the Americans of Philadelp[h]ia as to his conduct, one thing and another... he also had Portraits of General Washington, his wife, Governor Penn, and various others." 77 Taboca's journeys had helped him to gain access to this esoteric source of power based on contact with foreign peoples and the accumulation of knowledge, and such spiritual forms of power still resonated loudly as a basis of authority within late-eighteenth-century Choctaw society.

Other Choctaws also traveled within the seaboard states in subsequent years. For example, a small delegation of Choctaws (most likely from the eastern division) traveled to Charleston, South Carolina, within two months of the Hopewell meetings. Like Taboca, they also requested that trade be increased as soon as possible, and they offered to assist the Americans in their ongoing conflicts with the Creeks as an additional incentive. The Choctaws knew that the southeastern states worried constantly about Creek intentions and feared their frequent small-scale attacks on American settlers. Although the Choctaws attempted to play on these fears in order to secure a more plentiful trade, more trade from South Carolina was not forthcoming. ${ }^{78}$

Indeed, increased trade, which was the primary reason that the Choctaws traveled to Hopewell in the first place, generally failed to materialize at all. No steady American trade with the Choctaws developed until the Choctaw Trading Factory was established at St. Stephens in 1802. Even as the Choctaw delegation prepared to leave

\footnotetext{
"Ross and Phelps, eds., "A Journey Over the Natchez Trace in 1792," 261 (quotation): Helms, Craft and the Kingly Ideal, 109-10, 128-31; and O'Brien, "Choctaws in a Revolutionary Age," Chap. 4. For further general analysis of esoteric knowledge as a basis of elite authority in native societies, see Helms, Ulysses' Sail.

${ }^{7 x}$ Antonio Pace, trans, and ed., Luigi Castiglioni's Viaggin: Travels in the United States of North America, 1785-1787 (Syracuse, N.Y., 1983), 132-34; and Gentleman's Magazine (London), LXXVIII (May 1786), 433-34.
} 
Hopewell on January 6, 1786, they registered their disappointment with the undersupplied Americans. "The Indians appeared perfectly satisfied with everything except the Guns," wrote Joseph Martin, "as instead of Musquets they had been promised before they left the Nation that they should receive some Guns of the Manufacture of the United States of America and that ... were rifles." ${ }^{79}$ Of the Choctaw delegation to Hopewell, only Yockonahoma received a rifle; the other chiefs received muskets, with which they were understandably less than satisfied. Led to believe that the United States was a new and powerful nation capable of providing large quantities of trade goods, they discovered instead that the young republic was financially poor. The commissioners spent $\$ 1,181$ on their meeting with the Choctaws at Hopewell, a sum that far exceeded what they had intended to spend. Since rifles were in short supply in the United States and the national government suffered from perpetual lack of money, it seems unlikely that the American delegation to Hopewell ever intended to initiate a consistent trade relationship with the Choctaws. Only when confronted with intractable Indian groups who refused to accept their role as conquered peoples did the United States look to trade (and the consequent debts that it caused) as a tool to better influence Indian actions. ${ }^{80}$

Although southern states threw up roadblocks to the federal management of Indian affairs, these are an inadequate explanation for the obstacles that the United States encountered in their meetings at Hopewell. Southern Indians, as the Choctaw example demonstrates, resisted efforts by the United States to redefine their status as something other than sovereign. In their assumed role as conquerors, U.S. officials expected Indians in the post-Revolutionary era to realizeeven if not to fully accept - their subordinate role in the new North American order. However, most Indian groups east of the Mississippi River never lost a battle, much less a war, to the Americans, and, beginning in the 1780 s, their goals appeared to clash fundamentally with those of the United States. Many Indian groups responded to American arrogance and encroachment on their lands with violence, as

\footnotetext{
79) On January 6 the U.S. commissioners directed interpreter John Pitchlynn "to hurry the departure of the Indians as early tomorrow as possible"; however, for reasons unknown, the Choctaws did not depart until January 12. See Martin journal, 92 (quotations); Hawkins's transcription of Martin's journal [n.p., 18]; and American State Papers, IV, 50.

${ }^{80}$ Martin journal. 92; Hawkins's transcription of Martin's journal, [n.p., 18]: and American State Papers, IV. 50. For the government's promotion of debt among Indians in the early republic period see Braund, Deerskins and Duffels, 178. On the shortage of guns in the United States during this period see Michael A. Bellesiles, "The Origins of Gun Culture in the United States, 1760-1865." Joumal of American History, LXXXIII (September 1996), 425-55.
} 
in the recurrent warfare between Creek Indians and Georgians, and the Miami war chief Little Turtle's multi-tribal war against American settlements in the Ohio Valley during the 1790s. Increasingly aware that Indians from the Great Lakes to the Gulf of Mexico rejected the role that the United States preferred them to play and that the world was casting a critical eye on the new republic's bullying tactics, government officials such as Henry Knox insisted that the United States try to work with Indians rather than simply impose terms on them. By 1789 the United States had renounced its claims of absolute sovereignty over the territory it had acquired from Great Britain, thus converting Indian affairs from a domestic problem to a foreign policy issue. ${ }^{81}$ In other words, the United States acknowledged Indian autonomy and sovereignty in areas like the Old Southwest because there was little alternative. In subsequent decades, new American strategies developed concurrently to remove Indians from lands east of the Mississippi River, including negotiating with Indians for land cessions; warring against them to acquire undisputed title to new territory; promoting trade relations to encourage financial indebtedness; and insisting that Indians adopt the tenets of "civilization." 82

Stubborn Choctaw adherence to a centuries-old diplomatic style drove home the message that, despite its desires, the U.S. government could not dictate terms to Indians who refused to accept passively the notion of a new order that placed them on the losing side. EuroAmericans of different types may have lived all around them, but the Choctaws would make their own decisions about how to handle this rapidly changing universe. Native groups still constituted the dominant powers in the late-eighteenth-century southcastern Mississippi Valley, a notion that the Choctaws accepted as a matter of fact and that the Hopewell negotiations did little to change. Rather than bringing the two peoples closer together as Taboca, the other Choctaw dignitaries, and even the American delegates had hoped, the treaty council and its aftermath drove home the point that, for the foreseeable future, the southern backcountry frontier would comprise a contested zone with

\footnotetext{
$204-5$

"Jones, Lirense for Empire, 147-55; and Merrell, "Declarations of Independence," esp.

${ }^{82}$ Horsman, Expansion and American Indian Policy, 171-73; Wilcy Sword. President Washington's Indian War: The Struggle for the Old Northwest, 1790-1796 (Norman, Okla., 1985); Bernard W. Sheehan, Seeds of Extinction: Jeffersonian Philanthropy und the American Indian (Chapel Hill, 1973); Michael Paul Rogin, Fathers and Children: Andrew Jackson and the Subjugation of the American Indian (New York, 1975); and Ronald N. Satz, American Indian Policy in the Jacksonian Era (Lincoln, Neb., 1975).
} 
little room for compromise or intercultural cooperation between the United States and Indian groups. The possibilities suggested by the joining together of fictive kin crashed on the rocky shore of cultural misunderstanding and obstinacy. One side would need to yield and accept portions of the other culture's values before true collaboration and harmony could have any chance of success.

Careful analysis of the ceremonial and diplomatic context in which the Choctaw Hopewell Treaty was negotiated thus reveals a very different picture than does an analysis based on the treaty document alone. The Choctaw delegation made demands, conducted rituals, educated the U.S. representatives about their culture, and left Hopewell unsatisfied. The U.S. commissioners complained about Choctaw ignorance and also worried that little of value had resulted from the meeting. Both sides adhered to a rigid agenda and resisted compromise at Hopewell.

Viewing the treaty through the eyes of both sets of participants, however, reveals two societies acting in accordance with inherited tradition as well as employing new approaches born out of the Revolutionary War experience. Even though neither side had the power to coerce concessions from the other, the Choctaws insisted that their American counterparts act according to Choctaw notions of proper diplomatic conduct. Although they had conducted diplomatic meetings with Europeans for nearly a century and accepted the Euro-American insistence on written documents as a formalized record of any treaty proceeding, the Choctaws were more concerned to uphold their own rituals, speeches, and sacralized objects as the true record of negotiations. And even though American officials recognized the need to accommodate Indian notions of diplomatic procedure, they did so in a largely perfunctory manner that caused misunderstanding, misinterpretation, and disagreements about the meaning of the Hopewell Treaty in later years. In that sense, U.S. acquiescence to Choctaw rituals was merely a grease to lubricate the machinery that produced a written, legally-binding document and thus lacked the sincerity needed to make the agreement work.

Hence the "middle ground" of Indian-European interaction emphasized by recent scholars did not always consist of an area where different peoples enacted a "vision of peaceful coexistence and creative accommodation." Instead, as Richard White insisted in his seminal work, frontier zones comprised contested spaces where the meanings of rituals and words were argued over and contentions over power 
persisted. ${ }^{83}$ As an analysis of the Hopewell treaty proceedings between the Choctaws and the United States demonstrates, peaceful meetings could just as easily be characterized by intransigence and miscommunication. In this case, the Choctaws dominated the process of treatymaking and assumed the continuation of their absolute sovereignty and control over their own destiny; the Americans, on the other hand, arrived at Hopewell believing in their own cultural superiority and left thinking that all of the components of their pre-planned treaty had been agreed upon. But the historical realization of the character and outcome of intercultural encounters like Hopewell can only stem from a sensitive reading of the entire context in which such negotiations-or contests-occurred.

${ }^{83}$ Cayton and Teute, eds., Contact Points, 9: White, Middle Ground, ix-xv. 